\title{
Effects of Moisture Content and Additives on the Fermentation Quality and Degradation of Glycoalkaloids in Potato (Solanum tuberosum) Vine Silage in Tibet
}

\author{
Zhou Juanjuan $^{1,2, \dagger}$, Wei Wei ${ }^{1,2, \dagger}$, Qin Aiqiong ${ }^{1,2, *}$, Samten $^{1,2}$, Tenzin-tarchen ${ }^{1,2}$, Li Bin $^{1,3, *}$ \\ ${ }^{1}$ State Key Laboratory of Hulless Barley and Yak Germplasm Research and Genetic Improvement, Lhasa, China \\ ${ }^{2}$ Institute of Pratacultural Science, Tibet Academy of Agriculture and Animal Husbandry Science, Lhasa, China \\ ${ }^{3}$ Institute of Animal Husbandry and Veterinary, Tibet Academy of Agriculture and Animal Husbandry Science, Lhasa, China
}

\section{Email address: \\ xukesuolibin@163.com (Li Bin) \\ $\dagger$ Zhou Juanjuan and Wei Wei are co-first authors. \\ ${ }^{*}$ Corresponding author}

zhoujjcaoye@126.com (Zhou Juanjuan),weiweicc01@126.com (Wei Wei), qinaiqiong1975@163.com (Qin Aiqiong),

\section{To cite this article:}

Zhou Juanjuan, Wei Wei, Qin Aiqiong, Samten, Tenzin-tarchen, Li Bin. Effects of Moisture Content and Additives on the Fermentation Quality and Degradation of Glycoalkaloids in Potato (Solanum tuberosum) Vine Silage in Tibet Plateau. American Journal of Agriculture and Forestry. Vol. 7, No. 1, 2019, pp. 1-9. doi: 10.11648/j.ajaf.20190701.11

Received: November 22, 2018; Accepted: December 13, 2018; Published: January 24, 2019

\begin{abstract}
The objectives of this research were to evaluate the effects of raw material moisture content and additives on the fermentation quality and degradation of glycoalkaloids in potato vine silage and to explore new approaches for feedstuff preservation with the aim of providing a source of sustainable livestock feed. Potato vine was partially wilted to three different target moisture contents [approx. 75\% (M1), 65\% (M2), and 55\% (M3)] and treated with (1) formic acid [1.5\% fresh weight (FW), FA]; (2) pre-fermented juices (5.0 mL kg-1 FW, PFJ); (3) corn flour (100 $\left.\mathrm{g} \mathrm{kg}^{-1} \mathrm{DM}, \mathrm{CF}\right)$; (4) potato pulp (30\% FW, $\mathrm{PP})$; and (5) no additives (control). After 45 days of ensiling with polyethylene $(100 \mathrm{~mL})$, the fermentation quality, chemical composition, and concentration of glycoalkaloids were determined. The results showed that silage quality and glycoalkaloid concentration were significantly influenced by moisture content and additives $(P<0.05)$. Lactic acid (LA), $\mathrm{pH}$, acid detergent fiber (ADF), and neutral detergent fiber (NDF) increased slightly with decreasing moisture content; in contrast, the concentration of LA/AA declined. LA content was highest and $\mathrm{pH}$ and acetic acid (AA) were lowest at M1 compared with M2 and M3. Little to no butyric acid (BA) was detected in the presence of additives. The FA-treated silage exhibited a significantly reduced $\mathrm{pH}$ value and ammonia-N/total- $\mathrm{N}\left(\mathrm{NH}_{3}-\mathrm{N} / \mathrm{TN}\right)$ content $(P<0.05)$ and an increased concentration of LA and watersoluble carbohydrates (WSCs). PP-treated silage provided sufficient fermentation substrate, and the DM and WSC contents increased significantly $(P<0.05)$ compared with the PFJ and CF treatments. Supplementation with PFJ resulted in the $\mathrm{pH}$ of the ensiled forage stabilizing at approximately 4.40. With the addition of CF, the LA:AA ratios of the different moisture content treatments were $2.42,2.15$, and 1.75 , respectively, which were significantly lower than $3: 1$ in the other treatments at all moisture contents. The potato glycoalkaloid content of the PV silage increased with decreasing moisture level. Glycoalkaloid concentration was significantly reduced to $0.55,4.57$, and $7.73100 \mathrm{mg} \mathrm{g}^{-1}$, respectively $(P<0.05)$, in the different moisture treatments by the addition of FA. In conclusion, the best quality PV silage was produced at $75 \%$ moisture content with the addition of FA. Additive ensiling thus constitutes an effective approach for potato vine preservation.
\end{abstract}

Keywords: Additives, Fermentation Quality, Lactic Acid Bacteria, Moisture, Potato Vine Silage, Tibet

\section{Introduction}

The Qinghai-Tibet Plateau is a globally important ecological region wherein animal husbandry constitutes the primary industry. Livestock feed shortages are increasingly becoming one of the principal challenges in livestock production and development worldwide. It is therefore 
imperative that the use of potential nonconventional alternatives, such as agricultural industry by-products or straw, is explored for application in animal feed.

Potato (Solanum tuberosum $L$.) is one of the top four-most cultivated food crops of the Tibetan Plateau, with an annual cultivation area of approximately 16 thousand hectares [1] and an annual potato vine yield of 240 thousand tons [2]. Potato vine typically contains $80-260 \mathrm{~g}$ crude protein (CP) $\mathrm{kg}^{-1}$ dry matter (DM), 230-453 g neutral detergent fiber (NDF) $\mathrm{kg}^{-1} \mathrm{DM}$, and the intermediate solanesol, which is used in ubiquinone drug synthesis [3, 4]. This dry matter and fiber could potentially constitute valuable fodder for ruminants. However, fresh potato vine is not a suitable feed for ruminants because of its poor palatability and high glycoalkaloid content $[5,6]$, and it is thus considered as waste [7].

Ensiling is regarded as an efficient way to maintain the nutritive value and improve the palatability of forage. Recent studies have focused on the use of conventional alternatives, such as alfalfa (Medicago sativa L.) [8], corn (Zea mays L.) [9], and oats (Avena sativa L.) [10]. The optimization of moisture content and additives has also been addressed [11, 12]. The initial moisture content greatly influences silage characteristics by facilitating the fermentation process [13], and the addition of formic acid (FA) to the silage effectively inhibits microbial activity [14-16]. Zhu et al. [16] showed that pre-fermented juices could significantly increase dry matter and water-soluble carbohydrate concentration, as well as decreased protein degradation $(P<0.05)$ and improved the fermentation quality of alfalfa silage. Potato pulp is one waste product that is not efficiently utilized and has potential to be used as a substrate for improving ensiling quality due to its high vitamin and pectin contents [17]. In addition, the polyphenol oxidase and caffeic acid present in potato pulp are inhibitors of protein degradation [18]. Zhang et al. [19] reported that the combination of potato pulp and rice straw resulted in an increase of crude protein $(\mathrm{CP})$, water-soluble carbohydrate (WSCs) and lactic acid $(P<0.05)$, as well as decreased $\mathrm{pH}$ and neutral detergent fiber (ADF) contents in rice straw. Substantial efforts are currently being made to develop new and improved ensilage treatments, but few studies have focused on the use of agricultural by-products. Currently, most studies on potato vine have reported on glycoalkaloids chemical composition and have explored the ensiling process [20,4], and glycoalkaloid toxicity in small ruminants $[21,22]$, whereas limited studies on evaluating the degradation of glycoalkaloids, and the quantitative degradation of potato glycoalkaloids during ensiling [7, 23].

The objectives of the present study were to investigate the effects of raw material moisture content and additives on the fermentation quality and degradation of potato glycoalkaloids in potato vine silage and determine the optimal moisture content and additives conditions, our aim was to explore the efficient development and utilization of the agricultural by-product potato vine as a source of sustainable livestock feed.

\section{Materials and Methods}

\subsection{Forage and Ensiling}

\subsubsection{Ensilage Preparation Procedure}

Potato was harvested at the mature stage. Fresh potato vine was obtained from the experimental field of the Institute of Vegetable, Tibet Academy of Agriculture and Animal Husbandry Science. The potato vines were cut at approximately 8 to $10 \mathrm{~cm}$ above the ground using a sickle, and then chopped into $2-3 \mathrm{~cm}$ segments. Before ensiling, the chemical composition of the potato vine sample was measured as shown in Table 1.

Table 1. Chemical components of potato vine.

\begin{tabular}{lllllll}
\hline Item & WSC (\% DM) & CP (\% DM) & NDF (\% DM) & ADF (\% DM) & BC (mE kg-1 DM) & Potato glycoalkaloids (mg 100g ${ }^{-1}$ DM) \\
\hline Potato vines & $3.68 \pm 0.17$ & $18.49 \pm 0.65$ & $35.33 \pm 1.03$ & $29.60 \pm 0.55$ & $694.11 \pm 6.13$ & $107.06 \pm 4.25$ \\
\hline
\end{tabular}

Note: Water-soluble carbohydrate, WSC; crude protein, CP; neutral detergent fiber, NDF; acid detergent fiber, ADF; buffering capacity, BC; dry matter, DM.

Corn meal (CM) was purchased from the supermarket. Potato pulp (PP) was kindly provided by the Hengxin starch factory in Dingxi (Gansu, China) (175 g pectin $\left.\mathrm{kg}^{-1}, \mathrm{DM}\right)$. Analytical grade formic acid (FA) (85\%) was obtained from Beijing Chemical Works (Beijing, China).

The preparation of the pre-fermented juices (PFJ) followed the method of Song et al.[24]. Briefly, $200 \mathrm{~g}$ of the preensiling sample with homogenized by placing in a blender with $1000 \mathrm{~mL}$ deionized water and blending for $30 \mathrm{~min}$ at room temperature. Following this, the mixture was filtered through two layers of pledget. After the addition of $2 \%$ sucrose, the filtrate was shaken and quickly placed into a brown glass bottle and fermented for $48 \mathrm{~h}$ at $30^{\circ} \mathrm{C}$ in an incubator.

\subsubsection{Ensiling}

The chopped potato vine was partially wilted to three different target moisture contents [approx. 75\% (M1), 65\% (M2), and 55\% (M3)], and the moisture contents were continuously measured using an inductive moisture meter and microwave oven. They were divided into different equal parts and mixed in the following treatments: (1) $1.5 \% \mathrm{FA}$ (A1) on a FW basis; (2) $1.5 \%$ PFJ (A2) on a FW basis; (3) $100 \mathrm{~g} \cdot \mathrm{kg}^{-1} \mathrm{CF}$ (A3) on a DW basis; (4) $30 \%$ PP (A4) on a FW basis; and (5) no additives (control). The experimental design is indicated in Table 2. After mixing thoroughly, the ensiling materials were packed into the silos $(100 \mathrm{~mL}$ polyethylene plastic vials) and sealed with a screw top and Parafilm. Each silo was prepared in five replicates. All silos were stored indoors for $45 \mathrm{~d}$ at an ambient temperature of approximately $22 \pm 2^{\circ} \mathrm{C}$. 
Table 2. Experimental design.

\begin{tabular}{llllll}
\hline $\begin{array}{l}\text { Moisture } \\
(\%)\end{array}$ & content & Additives & & & \\
\cline { 2 - 6 } & Formic acid (A1) & Pre-fermented juices (A2) & Corn flour (A3) & Potato pulp (A4) & Control (A5) \\
\hline 75 (M1) & M1 A1 & M1 A2 & M1 A3 & M1 A4 & M1 Control \\
65 (M2) & M2 A1 & M2 A2 & M3 A3 & M2 A4 & M2 Control \\
55 (M3) & M3 A1 & M3 A2 & M3 A4 & M3 Control \\
\hline
\end{tabular}

\subsection{Chemical Composition Analyses}

\subsubsection{Sensory Evaluation}

After opening the silos, the color, odor, and texture were used to evaluate the quality of the silage.

\subsubsection{Fermentation Metabolite Analysis}

Water extracts of the silages were prepared by placing $20 \mathrm{~g}$ pulverized feedstuff and $180 \mathrm{~mL}$ deionized water into an Erlenmeyer flask, which was then kept in a refrigerator at $4^{\circ} \mathrm{C}$ for $24 \mathrm{~h}$. The homogenate was then filtered through four layers of pledget and one layer of qualitative filter paper. Water extracts were stored at $-20^{\circ} \mathrm{C}$ for the determination of $\mathrm{pH}$, buffering capacity (BC), $\mathrm{NH}^{3}-\mathrm{N}, \mathrm{LA}$, and volatile fatty acid (VFA) contents. The $\mathrm{pH}$ value was measured directly using a pH meter (PHS-3C, Ray Magnetic Instrument Factory, Shanghai, China). Buffering capacity was determined using the hydrochloric acid-sodium hydroxide method of Playne and McDonald [25]. The concentration of $\mathrm{NH}^{3}-\mathrm{N}$ was determined according to a colorimetric method [26]. The thawed extracts were centrifuged for $15 \mathrm{~min}$ at $10,000 \mathrm{rpm}$ and filtered through a dialyzer (pore size of 0.22 $\mu \mathrm{m})$ for the determination of LA and VFAs by highperformance liquid chromatography (HPLC) on an Agilent 1100 series HPLC [Agilent Technologies, Santa Clara, CA, USA; HP1100LC model, KC-811 column $(15 \mathrm{~cm} \times 4.6 \mathrm{~mm} \times 5$ $\mu \mathrm{m})$, ultraviolet detector G1314B]. The mobile phase was $0.01 \mathrm{~mol} \mathrm{~L}^{-1} \quad \mathrm{NaH}_{2} \mathrm{PO}_{3}$ (disodium hydrogen phosphite) solution, and the $\mathrm{pH}$ was approximately 2.32 ; the column temperature was $35^{\circ} \mathrm{C}$; the injection volume was $10 \mu \mathrm{L}$; the flow rate was $1.0 \mathrm{~mol} \mathrm{~min}^{-1}$; and the measured wavelength was $210 \mathrm{~nm}$.

\subsubsection{Pre-ensiling and Silage Analysis}

The pre-ensiled materials and ensiled samples were dried at $65^{\circ} \mathrm{C}$ for $48 \mathrm{~h}$ for $\mathrm{DM}$ calculation according to the procedure of Yang [27] and then passed through a $1 \mathrm{~mm}$ screen and stored at $4^{\circ} \mathrm{C}$ until further analysis. The watersoluble carbohydrate (WSC) concentration was determined colorimetrically after reaction with anthrone reagent [28]. The methods of Van Soest et al.[29] were used for the determination of NDF and ADF. The CPs were analyzed using a FOSS analyzer (FOSS Electric, Denmark) following the Association of Official Analytical Chemists (AOAC) procedure for protein determination [30].

\subsection{Potato Glycoalkaloid Analysis}

$\alpha$-Solanine standards (purity $\geq 99.8 \%$ ) were obtained from Sigma-Aldrich (St. Louis, MO, USA). Standard pure solanine $(0.0500 \mathrm{~g})$ accurately weighed and added to a $50 \mathrm{~mL}$ volumetric flask with $1 \%$ ammonium hydroxide solution, which constituted the standard solution of solanine. We then pipetted $0.5,1.0,1.5,2.0$, and $2.5 \mathrm{~mL}$ of the standard solution into the $5 \mathrm{~mL}$ volumetric flask, and the test solutions were measured at $530 \mathrm{~nm}$ using an ultraviolet spectrophotometer [31]. The standard curve of pure solanine was $\mathrm{y}=0.6767 \mathrm{x}+0.0054\left(R^{2}=0.9863\right)$.

Dry samples of pure potato vines or silages $(20 \mathrm{~g})$ were mixed with acidified alcohol (anhydrous ethanol: acetic acid $=100: 30, \mathrm{v} / \mathrm{v}$ ) and transferred into a $500 \mathrm{~mL}$ round-bottom flask, agitated with a magnetic stirrer for $15 \mathrm{~min}$ [31], and then filtered. The filtrate and samples were heated in a water bath at $55-65^{\circ} \mathrm{C}$ for $16 \mathrm{~h}$ in a Soxhlet extractor, following which the solvent was evaporated off using a rotary evaporator. All the samples were dissolved and washed with $5 \%$ sulfuric acid solution and then filtered through two layers filter paper again. Upon cooling, ammonium hydroxide was added until the $\mathrm{pH}$ of the filtrate was within the range of $10-11$. The filtrate was then centrifuged $\left(4^{\circ} \mathrm{C}\right)$ at $5000 \mathrm{rpm}$ for $15 \mathrm{~min}$ and the precipitates cleaned with $1 \%$ ammonium hydroxide solution. After re-centrifugation, the dried precipitate consisted of crude glycoalkaloids. The glycoalkaloids were dissolved in $1 \%$ sulfuric acid solution and combined with $10 \mathrm{~mL}$ water in a volumetric flask. From this latter solution, duplicate aliquots $(2 \mathrm{~mL})$ were mixed with $5 \mathrm{~mL}$ of $98 \%$ sulfuric acid, and after $3 \mathrm{~min}, 2.5 \mathrm{~mL}$ of $1 \%$ formaldehyde was added. After standing for $90 \mathrm{~min}$, the absorbance of the test solutions was determined at $530 \mathrm{~nm}$ using an ultraviolet spectrophotometer. The glycoalkaloid level was recorded as solanine equivalents $\left(\mathrm{mg}^{\left.100 \mathrm{~g}^{-1} \mathrm{DW}\right)}\right.$ by reference to the standard curve of pure solanine [32].

\subsection{Statistical Analysis}

A completely randomized design was used, and the data were evaluated using one-way analysis of variance (ANOVA) in SPSS 16.0 (SPSS Inc., Chicago, IL, USA). The results were presented as the mean and standard error (SE) of the mean. Differences between treatment means were determined by Duncan's multiple comparison tests. Significance was assessed at $P<0.05$.

\section{Results}

\subsection{Sensory Evaluation of the Potato Vine Silage}

The 15 different silage samples were evaluated based on three sensory parameters (color, odor, and texture). All the treatments, including the control, maintained a yellow-green color that was similar to the original color prior to silo storage. The samples had a mild sourness and slightly 
alcoholic odor, and no unpleasant odor was detected. The silage was devoid of mildew and had maintained a good shape after 45 days of ensiling. The alcoholic taste of the FA and PFJ treatments was more prominent than the control, $\mathrm{CF}$, and PP. The color of the potato vine ensilage without any additives was closer to yellow-brown.

\subsection{Fermentation Quality Evaluation of the Potato Vine Silage}

The effects of the different moisture contents and additives on the fermentation quality are indicated in Tables 3 and 5 . Moisture and additives significantly influenced the silage $\mathrm{pH}$, LA, AA, LA: AA, and $\mathrm{NH}_{3}-\mathrm{N}$ /total-N $\left(\mathrm{NH}_{3}-\mathrm{N} / \mathrm{TN}\right)(P<$ $0.05)$. In all silages, $\mathrm{pH}$ increased with decreasing moisture content, while, the concentration of LA was slightly reduced with decreasing moisture content. LA declined during the fermentation process, and only a relatively low amount of LA was detected in the FA, PFJ, CF, and PP treatments. No butyric acid (BA) was detected in the FA and PP treatments. LA content was highest and $\mathrm{pH}, \mathrm{AA}$, and $\mathrm{BA}$ were lowest at M1 compared to M2 and M3. In the control group, AA was higher than BA, and the concentrations of AA were lower in the treatment groups, with the exception of the CF treatments
(A3). AA increased with decreasing moisture content in A1, but decreased in $\mathrm{A} 3$ and $\mathrm{A} 4$. At M1, the lowest concentration of $\mathrm{NH}_{3}-\mathrm{N} / \mathrm{TN}$ was observed with the addition of FA or PP. The $\mathrm{NH}_{3}-\mathrm{N} / \mathrm{TN}$ content at M2 was lower with the addition of PFJ or CF than the M1 and M3 moisture contents.

At the three different moisture levels, the control treatments had the highest $\mathrm{pH}, \mathrm{BA}$, and $\mathrm{NH}_{3}-\mathrm{N} / \mathrm{TN}$ values and the lowest LA contents. Furthermore, the $\mathrm{pH}$, LA, and BA values differed significantly from the other four treatments $(P<0.05)$. The application of $\mathrm{CF}$ resulted in LA:AA ratios of $2.42,2.15$, and 1.75 at the three moisture levels, respectively, which was significantly lower than the other treatments. At M1, FA was associated with a significantly higher concentration of LA than the other treatments $(P<0.05)$. At $\mathrm{M} 1$, the $\mathrm{pH}$ values of $\mathrm{A} 1$ and $\mathrm{A} 4$ were 3.71 and 4.06, respectively (all of the values were lower than 4.20), which were significantly lower than A2 and A3 ( $P$ $<0.05)$. $\mathrm{NH}_{3}-\mathrm{N} / \mathrm{TN}$ was only $0.17 \% \mathrm{DM}$ at $\mathrm{M} 1$ with the addition of $\mathrm{FA}$, which suggests that $\mathrm{FA}$ could reduce protein loss. At M2, $\mathrm{NH}_{3}-\mathrm{N} / \mathrm{TN}$ in $\mathrm{A} 1$ was significantly lower than the other three treatments. At M3, $\mathrm{NH}_{3}-\mathrm{N} / \mathrm{TN}$ in $\mathrm{A} 2$ and $\mathrm{A} 3$ was $1.95 \% \mathrm{DM}$ and $2.41 \% \mathrm{DM}$, respectively, which was significantly higher than A1 and A4 $(P<0.05)$.

Table 3. Effects of moisture content and additives on the fermentation quality of potato vine silage.

\begin{tabular}{|c|c|c|c|c|c|c|}
\hline \multirow{2}{*}{ Item } & \multirow{2}{*}{ pH } & LA & $\mathbf{A A}$ & LA/AA & $\mathbf{B A}$ & \multirow{2}{*}{$\mathrm{NH}_{3}-\mathrm{N} / \mathrm{TN}(\%)$} \\
\hline & & \multicolumn{4}{|l|}{ (\% DM) } & \\
\hline $\mathrm{M}_{1} \mathrm{CK}$ & $4.92 \pm 0.05 \mathrm{a}$ & $0.93 \pm 0.06 \mathrm{e}$ & $0.65 \pm 0.03 b$ & $1.43 \pm 0.08 \mathrm{~b}$ & $0.16 \pm 0.07 a$ & $2.59 \pm 0.01 \mathrm{a}$ \\
\hline $\mathrm{M}_{1} \mathrm{~A}_{1}$ & $3.71 \pm 0.04 \mathrm{e}$ & $2.52 \pm 0.05 b$ & $0.09 \pm 0.07 \mathrm{~d}$ & $39.57 \pm 13.51 \mathrm{a}$ & - & $0.17 \pm 0.01 \mathrm{e}$ \\
\hline $\mathrm{M}_{1} \mathrm{~A}_{2}$ & $4.39 \pm 0.03 c$ & $1.47 \pm 0.09 \mathrm{~d}$ & $0.15 \pm 0.05 \mathrm{c}$ & $6.48 \pm 0.45 b$ & $0.03 \pm 0.03 b$ & $2.35 \pm 0.04 \mathrm{c}$ \\
\hline $\mathrm{M}_{1} \mathrm{~A}_{3}$ & $4.55 \pm 0.03 b$ & $3.56 \pm 0.07 a$ & $1.47 \pm 0.07 \mathrm{a}$ & $2.42 \pm 0.04 \mathrm{~b}$ & $0.16 \pm 0.03 b$ & $2.52 \pm 0.02 b$ \\
\hline $\mathrm{M}_{1} \mathrm{~A}_{4}$ & $4.06 \pm 0.04 \mathrm{~d}$ & $2.12 \pm 0.06 \mathrm{c}$ & $0.15 \pm 0.04 d$ & $10.29 \pm 1.43 b$ & - & $0.25 \pm 0.00 \mathrm{~d}$ \\
\hline $\mathrm{M}_{2} \mathrm{CK}$ & $5.13 \pm 0.24 a$ & $0.67 \pm 0.05 \mathrm{e}$ & $0.67 \pm 0.04 b$ & $1.03 \pm 0.08 \mathrm{c}$ & $0.53 \pm 0.04 a$ & $2.45 \pm 0.00 \mathrm{a}$ \\
\hline $\mathrm{M}_{2} \mathrm{~A}_{1}$ & $4.14 \pm 0.14 \mathrm{c}$ & $2.00 \pm 0.03 b$ & $0.41 \pm 0.00 \mathrm{c}$ & $4.97 \pm 13.51 b$ & - & $0.93 \pm 0.00 \mathrm{e}$ \\
\hline $\mathrm{M}_{2} \mathrm{~A}_{2}$ & $4.40 \pm 0.02 b$ & $1.46 \pm 0.07 \mathrm{~d}$ & $0.15 \pm 0.05 \mathrm{~d}$ & $3.00 \pm 0.45 b c$ & $0.03 \pm 0.04 \mathrm{c}$ & $1.79 \pm 0.02 \mathrm{c}$ \\
\hline $\mathrm{M}_{2} \mathrm{~A}_{3}$ & $4.60 \pm 0.02 b$ & $3.05 \pm 0.03 \mathrm{a}$ & $1.42 \pm 0.05 \mathrm{a}$ & $2.15 \pm 0.04 \mathrm{c}$ & $0.16 \pm 0.04 b$ & $2.36 \pm 0.00 \mathrm{~b}$ \\
\hline $\mathrm{M}_{2} \mathrm{~A}_{4}$ & $4.45 \pm 0.01 b$ & $1.76 \pm 0.05 \mathrm{c}$ & $0.15 \pm 0.06 \mathrm{~d}$ & $10.24 \pm 1.44 \mathrm{a}$ & $0.07 \pm 0.06 \mathrm{c}$ & $1.11 \pm 0.01 \mathrm{~d}$ \\
\hline $\mathrm{M}_{3} \mathrm{CK}$ & $5.20 \pm 0.02 \mathrm{a}$ & $0.60 \pm 0.06 \mathrm{e}$ & $0.68 \pm 0.08 b$ & $0.90 \pm 0.10 \mathrm{~b}$ & $0.57 \pm 0.04 \mathrm{a}$ & $2.73 \pm 0.05 \mathrm{a}$ \\
\hline $\mathrm{M}_{3} \mathrm{~A}_{1}$ & $4.25 \pm 0.03 \mathrm{~d}$ & $1.96 \pm 0.07 b$ & $0.41 \pm 0.09 \mathrm{c}$ & $4.90 \pm 0.48 b$ & - & $1.02 \pm 0.00 \mathrm{e}$ \\
\hline $\mathrm{M}_{3} \mathrm{~A}_{2}$ & $4.40 \pm 0.18 \mathrm{~cd}$ & $1.49 \pm 0.13 d$ & $0.59 \pm 0.08 \mathrm{~d}$ & $3.07 \pm 0.28 \mathrm{~b}$ & $0.03 \pm 0.02 \mathrm{c}$ & $1.95 \pm 0.01 \mathrm{c}$ \\
\hline $\mathrm{M}_{3} \mathrm{~A}_{3}$ & $4.67 \pm 0.04 \mathrm{~b}$ & $.34 \pm 20.04 a$ & $1.34 \pm 0.06 \mathrm{a}$ & $1.75 \pm 0.03 \mathrm{~b}$ & $0.16 \pm 0.05 \mathrm{~b}$ & $2.41 \pm 0.01 b$ \\
\hline
\end{tabular}

Note: data are mean \pm standard error; different small letters in the same column under the same moisture content indicate a significant difference $(P<0.05)$; means not detectable.

\subsection{Chemical Composition of the Potato Vine Silage}

As shown in Table 4 and 6, significant interactions were found between moisture content and additives for DM, CP, $\mathrm{NDF}, \mathrm{ADF}$, and WSC after ensiling for $45 \mathrm{~d}(P<0.05)$. For all of the treatments, DM, ADF, and NDF exhibited a slightly increased trend with decreasing moisture content, while $\mathrm{CP}$ remained relatively constant. Additionally, in the control group, the WSC content in M2 $(1.14 \% \mathrm{DM})$ was higher than in M1 and M3, and the CP content in M2 (17.54\% DM) was lower than M1 and M3. In the A1 group, the WSC content in M1 was higher by $24.20 \%$ and $35.36 \%$ than M2 and M3, respectively. In the A3 and A4 treatments, the WSC content in $\mathrm{M} 2$ increased with decreasing moisture content.

Table 4. Effects of moisture content and additives on the nutritional components of potato vine silage.

\begin{tabular}{lllll}
\hline \multirow{2}{*}{ Item } & DM & CP & NDF & ADF \\
\cline { 2 - 5 } & & $\mathbf{( \% ~ D M )}$ & & \\
\hline $\mathrm{M}_{1} \mathrm{CK}$ & $27.80 \pm 0.17 \mathrm{bc}$ & $17.71 \pm 0.11 \mathrm{a}$ & $33.48 \pm 0.25 \mathrm{a}$ & $29.22 \pm 0.35 \mathrm{a}$ \\
$\mathrm{M}_{1} \mathrm{~A}_{1}$ & $26.24 \pm 1.28 \mathrm{~d}$ & $18.24 \pm 0.04 \mathrm{a}$ & $27.39 \pm 0.08 \mathrm{~d}$ & $24.00 \pm 0.60 \mathrm{~d}$ \\
$\mathrm{M}_{1} \mathrm{~A}_{2}$ & $26.71 \pm 0.33 \mathrm{~cd}$ & $16.74 \pm 0.64 \mathrm{~b}$ & $29.70 \pm 0.54 \mathrm{~b}$ & $25.61 \pm 0.29 \mathrm{c}$ \\
\hline
\end{tabular}




\begin{tabular}{|c|c|c|c|c|c|}
\hline \multirow{2}{*}{ Item } & \multirow{2}{*}{ DM } & $\mathbf{C P}$ & NDF & ADF & WSC \\
\hline & & \multicolumn{4}{|l|}{ (\% DM) } \\
\hline $\mathrm{M}_{1} \mathrm{~A}_{3}$ & $28.22 \pm 0.46 b$ & $16.19 \pm 0.35 b$ & $28.47 \pm 0.09 \mathrm{c}$ & $27.08 \pm 0.04 b$ & $0.92 \pm 0.02 \mathrm{~d}$ \\
\hline $\mathrm{M}_{1} \mathrm{~A}_{4}$ & $33.48 \pm 0.19 \mathrm{a}$ & $12.47 \pm 0.27 \mathrm{c}$ & $29.26 \pm 0.22 b$ & $26.20 \pm 0.49 b$ & $2.51 \pm 0.01 \mathrm{~b}$ \\
\hline $\mathrm{M}_{2} \mathrm{CK}$ & $38.61 \pm 0.12 b$ & $17.54 \pm 0.62 b$ & $34.55 \pm 0.39 \mathrm{a}$ & $30.99 \pm 0.64 \mathrm{a}$ & $1.14 \pm 0.10 \mathrm{e}$ \\
\hline $\mathrm{M}_{2} \mathrm{~A}_{1}$ & $37.16 \pm 0.16 \mathrm{c}$ & $18.44 \pm 0.30 \mathrm{a}$ & $29.76 \pm 0.36 \mathrm{~d}$ & $25.26 \pm 0.22 \mathrm{~d}$ & $3.76 \pm 0.02 \mathrm{a}$ \\
\hline $\mathrm{M}_{2} \mathrm{~A}_{2}$ & $36.99 \pm 0.40 c$ & $17.63 \pm 0.17 \mathrm{~b}$ & $32.80 \pm 0.45 b$ & $26.78 \pm 0.14 \mathrm{c}$ & $1.54 \pm 0.04 \mathrm{c}$ \\
\hline $\mathrm{M}_{2} \mathrm{~A}_{3}$ & $38.49 \pm 0.03 b$ & $15.93 \pm 0.16 \mathrm{c}$ & $32.41 \pm 0.29 b$ & $28.01 \pm 2.36 \mathrm{~b}$ & $1.44 \pm 0.00 \mathrm{~d}$ \\
\hline $\mathrm{M}_{2} \mathrm{~A}_{4}$ & $42.20 \pm 0.50 \mathrm{a}$ & $13.44 \pm 0.11 \mathrm{~d}$ & $30.86 \pm 0.31 \mathrm{c}$ & $26.37 \pm 0.23 c$ & $2.75 \pm 0.00 \mathrm{~b}$ \\
\hline $\mathrm{M}_{3} \mathrm{CK}$ & $47.41 \pm 0.14 b$ & $17.99 \pm 0.24 \mathrm{ab}$ & $35.54 \pm 0.39 \mathrm{a}$ & $31.14 \pm 0.38 \mathrm{a}$ & $1.03 \pm 0.03 \mathrm{e}$ \\
\hline $\mathrm{M}_{3} \mathrm{~A}_{1}$ & $46.34 \pm 0.28 \mathrm{~d}$ & $18.42 \pm 0.57 \mathrm{a}$ & $30.61 \pm 0.28 \mathrm{~d}$ & $26.56 \pm 0.16 \mathrm{~d}$ & $3.45 \pm 0.03 \mathrm{a}$ \\
\hline $\mathrm{M}_{3} \mathrm{~A}_{2}$ & $46.25 \pm 0.36 \mathrm{~d}$ & $18.34 \pm 0.07 \mathrm{a}$ & $32.28 \pm 0.33 c$ & $27.47 \pm 0.35 \mathrm{c}$ & $1.30 \pm 0.00 \mathrm{~d}$ \\
\hline $\mathrm{M}_{3} \mathrm{~A}_{3}$ & $46.91 \pm 0.34 c$ & $17.60 \pm 0.08 b$ & $33.50 \pm 0.40 \mathrm{~b}$ & $28.11 \pm 0.40 \mathrm{~b}$ & $1.47 \pm 0.04 \mathrm{c}$ \\
\hline $\mathrm{M}_{3} \mathrm{~A}_{4}$ & $50.10 \pm 0.38 \mathrm{a}$ & $14.22 \pm 0.12 \mathrm{c}$ & $31.69 \pm 0.37 \mathrm{c}$ & $26.75 \pm 0.34 d$ & $2.92 \pm 0.01 b$ \\
\hline
\end{tabular}

At the three different moisture levels, the control treatments had the lowest WSC contents and the highest ADF and NDF contents, all of which differed significantly from those of the other four treatments $(P<0.05)$. The application of FA had the highest concentration of WSC compared with the other three treatments. The DM and CP contents with the addition of PP were significantly higher than the other four treatments, and ADF and NDF were significantly lower than the control group $(P<0.05)$. The WSC content in A1 was significantly higher than the control and other treatment groups $(P<0.05)$. At M1, the DM content in A1 was significantly lower than the control, $\mathrm{A} 3$, and A4 $(P<0.05)$. The CP content in A4 was significantly lower than the other treatments $(P<0.05)$. The WSC content in A4 was significantly higher than the control at $318.33 \%(P$ $<0.05)$. At M2, the concentration of WSC in A1 (3.76\%) and A4 (2.75\%) was significantly higher compared to the control,
$\mathrm{A} 2$, and $\mathrm{A} 3$. In addition, the concentration of $\mathrm{CP}$ in $\mathrm{A} 4$ was lower than the control, A2, and A3. At M3, the WSC content in A4 was higher than the control by $183.50 \%$, and CP was lower than the control by $20.96 \%$.

\subsection{Glycoalkaloids in the Potato Vine Silage}

The effects of different moisture contents and additives on glycoalkaloids in the potato vine silage are presented in Table 5. The glycoalkaloid content of the potato vine silage increased with decreasing moisture content. At the three moisture levels, the glycoalkaloid concentrations in the

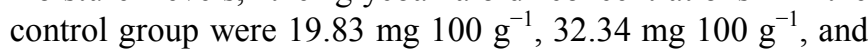
$40.94 \mathrm{mg} 100 \mathrm{~g}^{-1}$, respectively, which were significantly higher than the treatment groups $(P<0.05)$. The solanine content in M1 was the lowest among all the treatments.

Table 5. Effects of moisture content and additives on glycoalkaloid content in potato vine silage ( $\mathrm{mg} 100 \mathrm{~g}^{-1} \mathrm{DM}$ ).

\begin{tabular}{llllll}
\hline Item & Control & A1 & A2 & A3 & A4 \\
\hline M1 & $19.83 \mathrm{a} \pm 0.35$ & $0.55 \mathrm{e} \pm 0.40$ & $4.23 \mathrm{c} \pm 0.15$ & $12.60 \mathrm{~b} \pm 0.23$ & $3.32 \mathrm{~b} \pm 0.38$ \\
M2 & $32.34 \mathrm{a} \pm 0.23$ & $4.57 \mathrm{~d} \pm 0.26$ & $6.09 \mathrm{c} \pm 0.37$ & $15.28 \mathrm{~b} \pm 0.47$ \\
M3 & $40.94 \mathrm{a} \pm 0.11$ & $7.73 \mathrm{~d} \pm 0.17$ & $11.06 \mathrm{c} \pm 0.19$ & $19.22 \mathrm{~b} \pm 0.24$ \\
\hline
\end{tabular}

The FA, PFJ, CF, and PP treatments exhibited significantly decreased solanine concentrations $(P<0.05)$, and the addition of FA was associated with the lowest solanine content of only $0.55 \mathrm{mg} 100 \mathrm{~g}^{-1}$ (in M1). At M2 and M3, the glycoalkaloid contents in A2 and A4 were significantly lower than the control $(P<0.05)$; however, glycoalkaloid content did not differ significantly between A2 and A4.

Table 6. ANOVA of moisture content, additives, and their interaction.

\begin{tabular}{|c|c|c|c|c|c|c|c|c|c|c|c|c|}
\hline Item & pH & $\mathbf{L A}$ & $\mathbf{A A}$ & LA/AA & $\mathbf{B A}$ & $\mathrm{NH}_{3}-\mathrm{N} / \mathrm{TN}$ & DM & $\mathbf{C P}$ & NDF & ADF & WSC & PG \\
\hline $\mathrm{MC}$ & $44.06^{*}$ & $185.92 *$ & $14.57 *$ & $278.50 *$ & 0.93 & $587.44^{*}$ & $0.04 *$ & $50.58 *$ & 63.98* & $332.93 *$ & $22.14 *$ & $484.70^{*}$ \\
\hline A & $102.99 *$ & $802.13 *$ & $706.48^{*}$ & $397.12 *$ & $28.72 *$ & $0.00 *$ & $234.42 *$ & $467.76^{*}$ & $86.05^{*}$ & $92.06^{*}$ & $0.06^{*}$ & $1441.93 *$ \\
\hline $\mathrm{MC} \times \mathrm{A}$ & $13.83^{*}$ & $49.25 *$ & $10.11 *$ & $236.77 *$ & $0.93 * *$ & $855.01 *$ & $7.21 *$ & $7.73 *$ & $6.17 *$ & $13.13 *$ & $245.50 *$ & $42.07 *$ \\
\hline
\end{tabular}

Note: * indicates significant difference at $P<0.05$.

$\mathrm{MC}$, moisture content; A, additives.

\section{Discussion}

\subsection{Chemical Composition of the Pre-ensiled Materials}

Silage quality is influenced by the raw materials, moisture content, and the compaction degree [33, 34]. In addition, lower buffering capacity, and a certain amount of substrate (WSCs) should also be provided for lactic acid bacterial fermentation [35, 36]. Meeske et al. [37] reported that the $\mathrm{pH}$ value of ensiled corn with $107 \mathrm{~g} \cdot \mathrm{kg}^{-1}$ DM WSC could be reduced to less than 4.0 in two days. In the present study, preensiled potato vines had a low WSC (3.68\% DM, which is less than the minimum recommended level for ensiling) [38, 39], higher buffering capacity (694.11 mE kg-1 DM), and high moisture content $(85 \%-92 \%)$ [40], all of which are considered to render ensiling more difficult. McDonald et al. [38] showed that a low WSC accompanied by a high buffering capacity may result in a high $\mathrm{pH}$ in legume silage. 
A high $\mathrm{pH}$ value during ensiling does not create the optimal environment for the growth of aerobic microorganisms. Dunière et al. [41] reported that an adequate DM (30-40 g $\mathrm{kg}^{-1}$ ), lactic acid bacteria (LAB), and an initial WSC of more than $70 \mathrm{~g} \mathrm{~kg}^{-1}$ were required for satisfactory fermentation. An effective way to obtain satisfactory fermentation is to supplement with different additives that are highly soluble or can reduce $\mathrm{pH}$ rapidly, such as corn flour or organic acids.

\subsection{Effects of Moisture Content on the Fermentation Quality of Potato Vine Silage}

Moisture is the main factor influencing the fermentation quality of ensiled forage. Moisture is required by LAB for metabolic reactions and has a significant effect on the initial level and the transportation of oxygen during the ensilage process [42]. As critical $\mathrm{pH}$ values vary with moisture content [38], fermentation under higher moisture contents is accompanied by a lower critical $\mathrm{pH}$, and the growth of aerobic microorganisms is difficult to restrain under a low $\mathrm{pH}$, even at $\mathrm{pH}$ values below 4.0 [43]. When the moisture content is low, the remaining residual air will increase the risk of the proliferation of undesirable microorganisms [44].

In this study, a declining tendency in fermentation quality was observed with decreasing moisture content, as indicated by the high $\mathrm{pH}$ and low LA content of the ensilage. This corroborates the studies of Kim et al.[45] and Manyawu et al.[46]. A moisture content of $75 \%$ produced the best quality silage in this study. The silage treated with FA at $75 \%$ water content was well-preserved as indicated by the good fermentation characteristics, such as a lower $\mathrm{pH}$ value, lower $\mathrm{NH}_{3}-\mathrm{N} / \mathrm{TN}$, less WSC loss, and the absence of BA (Table 3). However, the concentration of $\mathrm{CP}$ at $55 \%$ moisture content was higher than at $75 \%$. The high variation in $\mathrm{CP}$ content observed was mostly likely a result of endogenous enzyme activity at the different moisture levels. Lower moisture conditions in raw materials that have been dried or wilted inhibit microbial activity, influence proteolysis in silages by restricting protein degradation [47] and enhance $\mathrm{CP}$ in CFtreated and PFJ-treated silages. The results from the present study suggested that the method of partial drying followed by ensiling may be an approach for biomass storage and stabilization.

\subsection{Effects of Additives on the Fermentation Quality of Potato Vine Silage}

At the three different moisture contents, all the treatments (FA, PFJ, CF, and PP) could improve the potato vine silage quality by enhancing the sensory quality and reducing the $\mathrm{pH}$ of the ensiled forage. Significant differences were observed in the BA generated at all moisture content levels $(P<0.05)$. High concentrations of both BA and NH3-N/TN were found in the CF-treated silages. The absence or relatively low amount of BA in the other treatments (FA, PFJ, and PP) indicated that the activity of Clostridium butyricum, which is produced during fermentation was reduced. Kung and Stokes [48] suggested that a LA to AA ratio of more than 3:1 would be an indication of more dominant homolactic fermentation. The LA: AA ratios with the addition of CF were 2.42, 2.15, and 1.75, respectively, which indicates that heterofermentative $\mathrm{LAB}$ dominated the ensiling system at the three different moisture contents, and the heterofermentative LAB process was advanced by the addition of CF. Alli et al. [49] found that molasses could facilitate heterofermentative $\mathrm{LAB}$ and result in the partial fermentation of LA to AA. Kung et al. [50] showed that treatment with ammonia could decrease the LA: AA ratio and increase the $\mathrm{NH}_{3}-\mathrm{N}$ concentration during ensiling. This may explain why high concentrations of both BA and $\mathrm{NH}_{3}-\mathrm{N} / \mathrm{TN}$ and a low WSC content were found in the CF-treated silages. The amount of $\mathrm{ADF}$ and NDF is an important variable influencing the fiber quality of the feed. The amount of ADF is a major factor affecting silage energy composition. Silage with a lower ADF concentration is more digestible and has greater nutritional value [51]. The concentration of $\mathrm{ADF}$ and $\mathrm{NDF}$ was significantly decreased with the addition of PP $(P<0.05)$. The partial degradation of cell walls during ensiling may account for the lower NDF and ADF contents in the potato pulp.

The addition of PFJ to silage suppresses mold growth [52]. Cao et al. [53] showed that the addition of PFJ to baled alfalfa silage could reduce the $\mathrm{pH}$ value from 5.66 to 4.66 compared with no additive. In this study, the addition of PFJ resulted in the $\mathrm{pH}$ of the ensiled forage stabilizing to approximately 4.40 after $45 \mathrm{~d}$, which was indicative of increased dominant homolactic fermentation. This finding was in agreement with the results of Song et al. [24].

In the current study, the CP contents of the fresh PV was $18.49 \%$ DM, which was comparable with the CP in alfalfa, corroborating the studies of Salehi et al. [23], Luo and Guo [40], and Muck et al. [3]. Potato vines constitute a potential protein source in ruminant diets and can partially replace protein fodder $[22,54]$. The $\mathrm{CP}$ contents of the control treatment were lower by approximately $3.5 \%$ compared with the FA-treated PV. The reduction in CP content could be attributed to nitrogen losses from protein degradation, which would explain why the addition of FA facilitates the ensiling process. FA resulted in good-quality silage with lower $\mathrm{pH}$ and NH3-N/TN values and a higher WSC content, and was previously found to rapidly reduce $\mathrm{pH}$ and restrict the reproduction of putrefying bacteria, such as Clostridium [55], as well as depress the activity of proteolytic enzymes [16]. Furthermore, the inclusion of FA preserved the soluble carbohydrates from the original material or those produced by polysaccharide conversion, and lead to the formation of microorganism protein [16], which is beneficial for ruminants.

\subsection{Effects of Potato Glycoalkaloids on Potato Vine Silage}

Potato vines are potential fodder sources; however, they are generally discarded as waste due to the presence of toxic glycoalkaloids, which are harmful to ruminants when provided in large quantities [7, 56-57]. Konig [20] reported that the toxic glycoalkaloid dose was typically $225 \mathrm{mg}$ 
$100 \mathrm{~g}^{-1}$ body weight for sheep. The adverse effect of potato glycoalkaloids in animals is related to their anticholinesterase activity in the central nervous system, cellular membrane disruption, induction of liver enzymes, teratogenicity, and embryotoxicity [58, 59].

In the present study, both wilting and ensiling reduced the concentration of the anti-nutritional components of potato vine. The potato glycoalkaloid content of the fresh potato vine was $107.06 \mathrm{mg} 100 \mathrm{~g}^{-1} \mathrm{DM}$ and was reduced to 19.83 ,

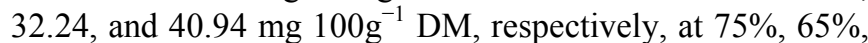
and $55 \%$ moisture contents after 45 days of ensiling. The toxicity levels of the treated silages (FA, PFJ, CF, and PP) ranged from 0.55 to $19.22 \mathrm{mg} 100 \mathrm{~g}^{-1} \mathrm{DM}$, with glycoalkaloid degradation rates of $53.04 \%$ to $97.23 \%$. This indicated that the majority of the glycoalkaloids were degraded during the potato ensiling process, which suggested that the silage might be safe for consumption by ruminants. This finding is consistent with that reported by Malecky et al. [22]. In the present study, the addition of FA at $75 \%$ moisture content resulted in the fastest degradation rate, while the slowest degradation was found in the CF-treated silage at $55 \%$ moisture content. The degradation levels appear to be correlated with the fermentation quality. Due to the fungal toxic properties of potato glycoalkaloids [60], it is necessary that LAB growth is improved in order to create an acidic environment. It can be concluded that glycoalkaloid degradation is associated with the transformation process of microbial degradation during acid-catalyzed hydrolysis [61]. Ensiling thus constitutes an effective means of reducing the glycoalkaloid content in potato vine.

\section{Conclusion}

Moisture content significantly influenced silage quality, and partial wilting followed by ensilage may improve the fermentation characteristics of fresh forage. Untreated potato vines do not stored well, and ensiling with additives (formic acid, pre-fermented juices and potato pulp) improved the fermentation quality of the silage with lower $\mathrm{pH}$ value and NH3-N/TN contents, and higher CP and WSC contents. The glycoalkaloid concentration of the potato vines was most effectively reduced by ensiling with formic acid, followed by the addition of pre-fermented juices and potato pulp. In conclusion, a moisture content of $75 \%+$ formic acid treatment performed the best. Based on the findings of this study, ensiling with additives is an effective and safe storage technique for preserving potato vines. Furthermore, protein fodder may be partially substituted by PV silage treated with additives without any adverse effect for ruminants, and can thus be utilized as a source of livestock feedstuff.

\section{Acknowledgements}

This research was funded by the projects of the National Key Research and Development Program of China (No. 2018YFD0502402), Tibet Autonomous Region Forage Program (No. 2018ZDKJZC-9), and Tibet Finances Program
(No. XZNKY-2018-C-030). All authors have read and approved the final manuscript.

\section{References}

[1] Dai X L, Liao W H, Zhuo G, Ma R P, Gao X L, Zhang Y H. 2014. Utilization prospects and strategies of potato in Tibet. Chinese Potato Journal, 28, 57-60. (in Chinese).

[2] Yuan J H, Han L M. 2016. Resource utilization of Potato vines. Journal of Traditional Chinese Veterinary Medicine, 35, 78-81. (in Chinese).

[3] Muck R E, Weinber Z G, Rouse D I.1999. Ensiling of potato vines. Transaction of the ASABE, 42, 565-572.

[4] He Y P, Guo Y L, Qin S Z, Ma S M, Du J J, Zhen C, Zhao F F. 2015. Effects of adding rice bran and wheat bran on silage quality of different cultivars of potato vines. Chinese Journal of Animal Nutrition, 27, 3311-3318. (in Chinese).

[5] Zhao X S, Li S Y, He D J, Wang J. 2013. Structure-antifungal activity relationships of potato glycoalkaloids. Science and Technology of Food Industry, 34, 159-163. (in Chinese).

[6] Nikolic N C, Stankovic M Z. 2005. Hydrolysis of glycoalkaloids from Solanum tuberosum L. haulm by enzymes present in plant material and by enzyme preparation. Potato Research, 48, 25-33.

[7] Nicholson J W G, Young D A, McQueen R E, De Jong H, Wood F A. 1978. The feeding value potential of potato vines. Canadian Journal of Animal Science, 58, 559-569.

[8] Liu C, Lai Y J, Lu X N, Guo P T, Luo H L. 2016. Effect of lactic acid bacteria inoculants on alfalfa (Medicago sativa $\mathrm{L}$.) silage quality: assessment of degradation (in situ) and gas production (in vitro). Journal of Integrative Agricultural, 15, 2834-2841.

[9] Chen L, Yuan X J, Li J F, Wang S R, Dong Z H, Shao T. 2016. Effect of lactic acid bacteria and propionic acid on conservation characteristics, aerobic stability and in vitro gas production kinetics and digestibility of whole-crop corn based total mixed ration silage. Journal of Integrative Agricultural, $15,1592-1600$.

[10] Zhang B Y, Zhao G Q, Jiao T, Chai J K, Gou Z Q, Xu X Z, Yan C T. 2017. Effects of different combinations of Oat hay and Whole corn silage on Ruminal fermentation of sheep. Chinese Journal of Animal Nutrition, 10, 3563-3573. (in Chinese).

[11] Thompson D N, Barnes J M, Houghton T P. 2005. Effect of additions on ensiling and microbial community of senesced wheat straw. Appl Biochem Biotechnol, 121, 21-46.

[12] Zheng Yi, Matthew Yates, Hnin Aung, Cheng Yu sheng, Yu Chaowei, Guo Hongyun, Zhang Ruihong, Jean Vander Gheynst, Bryan M. Jenkins. 2011. Influence of moisture content on microbial activity and silage quality during ensilage of food processing residues. Bioprocess Biosyst Eng, 34, 987-995.

[13] Li X X, Xu W B, Yang J S, Zhao H B, Xin H S, Zhang Y G. 2016. Effect of different levers of corn steep liquor addition on fermentation characteristics and aerobic stability of fresh rice straw silage. Animal Nutrition, 2, 345-350. 
[14] Ren H W, Dou Y W, Zhao T, Li X Y, Li Z Z, Li J P, Sun W J, Huang J J. 2016. Effects of additives on the mixed silage quality of corn stover and asparagus lettuces leaves. Acta Prataculturae Sinica, 25, 142-152. (in Chinese).

[15] Buxton D E. 2003. American Society of Agronomy-Crop Science Society of America-Soil Science Society of America. Silage science and technology, 305-361.

[16] Zhu Y H, Lian M N, Guo X S. 2013. Improve fermentation quality of alfalfa silage by addition of fermented juice prepared from Kobresia littledalei. Transactions of the Chinese Society of Agricultural Engineering, 29, 199-206. (in Chinese).

[17] Rigo E, Zsedely E, Toth T, Schmidt J. 2011. Ensilaging alfalfa with hydrolyzed corn meal additive and bacterial inoculant. Acta Agronomica Ovariensis, 53, 15-23.

[18] Cecava M J, Parker J E. 1993. Intestinal supply of amino acids in steers fed ruminally degradable and undegradable crude protein sources alone and in combination. Science of Anita, 71, 1596-1605.

[19] Zhang W, Zhang Y, Liu Z. 2012. Effect of different absorbents on fermentation quality of wet potato pulp. Journal of Animal and Veterinary Advances, 11, 4230-4235.

[20] Morris, S. C., Lee, T. H., 1984. The toxicity and teratogenicity of Solanaceae glycoalkaloids, particularly those of the potato (Solanum tuberosum). Food Technol, 36, 118-124.

[21] Konig H. 1953. Investigations concerning the action of solanine in cattle and sheep in connection with feeding potato foliage. Schweizer Archiv für Tierheilkunde. 95, 97-118.

[22] M Malecky, M Ghadbeigi, H Aliarabi, AA Bahari, K Zaboli. 2016. Effect of replacing alfalfa with processed potato vines on growth performance, ruminal and total tract digestibility and blood metabolites in fattening lambs. Small Ruminant Research, 146, 13-22.

[23] Salehi S, Lashkari S, Abbasi R E, Kamangar H. 2014. Nutrient Digestibility and Chemical Composition of Potato (Solanum tuberosum L.) Vine as Alternative Forage in Ruminant Diets. Agriculture Communications, 2, 63-66.

[24] Song G, Zhu X Q, Zhang S, Zhuang Y F. 2017. Effects of fermented green juice and cellulase on the fermentation quality of rice straw silage and rice straw with sugarcane tip mixed silage. Chinese Animal Husband \& Veterinary Medicine, 44, 3512-3518. (in Chinese).

[25] Playne M J, Mcdonald P. 1966. The buffering constituents of herbage and of silage. Journal of the Science of food and Agriculture, 17, 264-268.

[26] Chen L, Guo G, Yu C Q, Zhang J, Shimojo M, Shao T. 2014. The effects of replacement of whole-plant corn with oat and common vetch on the fermentation quality, chemical composition and aerobic stability of total mixed ration silage in Tibet. Animal Science Journal, 86, 69-76.

[27] Yang S.1999. Analysis o f feed and feed quality detection technology. (China Agricultural University Press), Beijing. pp.16-27.(in Chinese).

[28] Thomas T A. 2010. An automated procedure for the determination of soluble carbohydrates in herbage. Journal of the Science of Food and Agriculture, 28, 639-642.
[29] Van Soest P J, Robertson J B, Lewis B A. 1991. Methods for dietary fiber, neutral detergent fiber, and nonstarch polysaccharides in relation to animal nutrition. Journal of Dairy Science, 74, 3583-3597.

[30] AOAC (Association of Official Analytical Chemists). 2000. Official Methods of Analysis. Association of Official Analytical Chemists, Arlington, VA, USA.

[31] Zhang W, Xiong X Y, Li X. 2006. Extraction and analysis of solanine in potato. Journal of Hunan Agricultural University, 32, 665-667. (in Chinese).

[32] Haddadin M S Y, Humeid M A, Qaroot F A, Robinson R K. 2001. Effect of exposure to light on the solanine content of two varieties of potato (Solanum tuberosum) popular in Jordan. Food Chemistry, 73, 205-208.

[33] Zhang X F. 2004. Forage feed processing and storage. (China Agriculture Publishers), Beijing. pp. 5-33.

[34] Donald P M, Henderson A R, Herson D J E. 1991. The Biochemistry of Silage (2nd). (Chalcombe Publishers), Bucks. pp. 158.

[35] Amer S, Hassanat F, Berthiaume R, Seguin P, Mustafa A F. 2012. Effects of water soluble carbohydrate content on ensiling characteristics, chemical composition and in vitro gas production of forage millet and forage sorghum silages. Animal Feed Science and Technology, 177, 23-29.

[36] Moselhy M A, Borba J P, Borba A E. 2015. Improving the nutritive value, in vitro digestibility and aerobic stability of Hedychium gardnerianum silage through application of additives at ensiling time. Animal Feed Science and Technology, 206, 8-18.

[37] Meeske R, Basson H M, Cruywagen C W. 1999. The effect of a lactic acid bacterial inoculants with enzymes on the fermentation dynamics, intake and digestibility of digit aria epicanthi silage. Animal Feed Science and Technology, 81, 237-248.

[38] McDonald P, Henderson N, Heron S. 1991. The biochemistry of silage (2nd). (Chalcombe Publishers), Marlow. pp.340.

[39] McAllister T A, Hristov A N. 2000. The fundamentals of making good quality silage. Advances in Dairy Technology, $12,381-399$.

[40] Luo R R, Guo Y L. 2017. Research progress of silage modulation on potato vines. China Feed, 4, 34-37. (in Chinese).

[41] Dunière L, Sindou J, Chaucheyras-Durand F, Chevallier I, Thévenot-Sergentet D. 2013. Silage processing and strategies to prevent persistence of undesirable microorganisms. Animal Feed Science and Technology, 182, 1-15.

[42] Troller J A, Stinson J V.1981. Moisture requirements for growth and metabolite production by lactic acid bacteria. Applied Environmental Microbiology, 42, 682-687.

[43] Broderick G A, Walgenbach R P, Sterrenburing E. 2000. Performance of lactating dairy cows fed alfalfa or red clover silage as the sole forage. Dairy Science, 83, 1543-1551.

[44] Seppälä A, Heikkilä T, Mäki M, Rinne M. 2016. Effects of additives on the fermentation and aerobic stability of grass silages and total mixed rations. Grass and Forage Science, 71, $458-471$. 
[45] Kim J G, Chung E S, Seo S, Ham J S, Kang W S, Kim D A. 2001. Effects of maturity at harvest and wilting days on quality of round baled rye silage. Asian-Australasian Journal of Animal Science, 14, 1233-1237.

[46] Manyawu G J, Sibanda S, Mutisi C, Chakoma I C, Ndiweni P N B. 2003. The effect of pre-wilting and incorporation of maize meal on the fermentation of bana grass silage. AsianAustralasian Journal of Animal Science, 16, 843-851.

[47] Vissers M M, Driehuis F, Te Giffel M C, De Jong P, Lankveld J M. 2007. Concentrations of butyric acid bacteria spores in silage and relationships with aerobic deterioration. Journal of Dairy Science, 90, 928-936.

[48] Kung L Jr, Stokes M R. 2001. Analyzing silages for fermentation end products. University of Delaware College of Agriculture \& Natural Resources.

[49] Alli I, Fairbairn R, Noroozi E, Baker B E. 2006. The effects of molasses on the fermentation of chopped whole-plant leucaena. Journal of the Science of Food and Agriculture, 35, 285-289.

[50] Kung L Jr, Robinson J R, Ranjit N K, Chen J H, Golt C M, Pesek J D. 2000. Microbial populations, fermentation endproducts, and aerobic stability of corn silage treated with ammonia or a propionic acid-based preservative. Journal of Dairy Science, 83, 1479-1486.

[51] Kung L Jr, Taylor C C, Lynch M P. 2003. The effect of treating alfalfa with Lactobacillus bunchneri 40788 on silage fermentation, aerobic stability, and nutritive value for lactating dairy cows. Journal of Dairy Science, 86, 336-343.

[52] Yu Zhu. 2002. Studies on grass silage. China Agricultural University Postdoctoral Research Report. (in Chinses).

[53] Cao L M, Goto M, Karita S, Yamamoto Y, Mizutani M. 2002. Effect of fermented juice of epiphytic lactic acid bacteria on the fermentation quality of alfalfa (Medicago sativa L.) silage and its energy and nitrogen utilization by dry cows. Japanese Journal of Grassland Science, 8, 227-235.
[54] Noordar H, Malecky M, Najafabadi. H J, Navidshad B. 2017. Evaluating nutritional value of processed potato vines by in vitro gas production. New Zealand Journal of Agricultural Research, 60, 189-204.

[55] Zheng H C, Yang J Y, Ying R L, Huang X, Wu J L, Jiang Y Q. 2017. Effects of wilting and additives on fermentation quality and nutritional value of round-baled rice straw silages. Chinese Journal of Animal Nutrition, 29, 1312-1318. (in Chinese).

[56] Friedman M. 2006. Potato glycoalkaloids and metabolites: roles in the plant and in the diet. Journal of Agriculture and Food Chemistry. 54, 8655-8681.

[57] Walker AM. 1997. The effect of $\alpha$-solanine on acetylcholinesterase activity in vitro: an examination of undocumented beliefs. Unpublished thesis, University of Manitoba, Winnipeg, Manitoba.

[58] Caldwell K A, Grosjean O K, Henika P R, Friedman M. 1991. Hepatic ornithine decarboxylase induction by potato glycoalkaloids in rats. Food Chem, 29, 531-535.

[59] Toyoda M, Rausch W D, Inoue K, Ohno Y, Fujiyama Y, Takagi K, Saito Y. 1991. Comparison of solanaceous glycoalkaloids-evoked calcium influx in different types of cultured cells. Toxicol, 5, 347-351.

[60] Langkilde S, Schroder M, Stewart D, Meyer O, Conner S, Davies H, Poulsen M. 2008. Acute toxicity of high doses of the glycoalkaloids, alpha-solanine and alpha-chaconine, in the Syrian Golden hamster. Journal of Agriculture and Food Chemistry, 56, 8753-8760.

[61] Friedman M, McDonald G, Haddon W F. 1993. Kinetics of acid-catalyzed hydrolysis of carbohydrate groups of potato glycoal-kaloids alpha-chaconine and alpha-solanine. Journal of Agriculture and Food Chemisgry, 41, 1397-1406. 